\title{
THE USE OF NEW INSERTER (R_INSERTER) FOR DELIVERING CUT-380A IUD DURING POSTPARTUM PERIOD PHASE II CLINICAL TRIAL
}

\author{
Risanto Siswosudarmo ${ }^{1}$, Kadek Kurniawan ${ }^{2}$, Herdhana Suwartono ${ }^{3}$, Taufik Rahman Alkaff ${ }^{4}$, \\ and Maria Anggraeni ${ }^{5}$
}

\begin{abstract}
ABSTRAK
Latar Belakang: IUD adalah salah satu alat kontrasepsi jangka panjang yang efektif, tetapi penggunaan di Indonesia masih rendah. Karena inserter IUD yang biasa di pakai terlalu pendek untuk pemasangan segera pascasalin maka bentuk inserter baru ( $R \_$inseter) telah dikembangkan.

Tujuan: Untuk mengetahui apakah $\mathrm{R}$ inserter dapat digunakan dengan mudah sesuai standard pemasangan IUD dan untuk mengetahui keamanannya.

Metode: Uji klinis fase II, post test observation.

Bahan dan cara: IUD yang dipasang adalah TCu380A dengan modifikasi pada inserternya (R_inserter) buatan PT Kimia Farma. Penelitian ini dilakukan di 3 Rumah Sakit dan 3 Puskesmas yang merupakan afiliasi rumah sakit pendidikan Dr Sardjito dari bulan Januari 2012 sampai April 2013. Semua klien yang memenuhi kriteria inklusi dan eksklusi dimasukkan dalam penelitian ini. Pemasangan dilakukan oleh Residen atau Bidan yang telah mendapatkan pelatihan. Follow up dilakukan setelah 1 minggu, 1, 3, 6, 9 dan 12 bulan pascapasang. Kemudahan, angka ekspulsi, infeksi, nyeri, perdarahan, dan angka kelangsungan merupakan hasil utama yang diobservasi.

Hasil dan Pembahasan: Selama kurun waktu tersebut telah direkrut sebanyak 142 klien yang memenuhi kriteria kelayakan. Lama pemasangan rata-rata adalah 3,89 $\pm 2,08$ menit dengan minimum 2 menit dan maksimum 10 menit. Tidak ada kesulitan yang dirasakan. Secara kumulatif kejadian dalam 1, 3, 6, 9 dan 12 bulan untuk ekspulsi masing-masing adalah 9,9\%, 9,9\%, 10,6\%, 10,6\% dan 10\%. Angka ekspulsi jika IUD dipasang dalam 10 menit pertama setelah plasenta lahir adalah 6,2\% dibanding 24,1\% bila pemasangan dilakukan setelah 10 menit (RR 3,90; $95 \% \mathrm{Cl}$ 1,37-11,2). Kejadian seperti infeksi, nyeri dan perdarahan relatif kecil dan dapat diatasi. Angka kelangsungan selama 1, 3, 6, 9 dan 12 bulan berturut turut adalah 89,4\%, 89,4\%, 86,6\% 86,6\% dan 85,9\%. Tidak dijumpai kehamilan pada penelitian ini.

Kesimpulan: R_inserter dapat dipakai untuk memasang IUD CuT-380A dengan mudah dan aman. Angka kejadian ekspulsi tertinggi terjadi dalam satu bulan pertama pascapasang dan berhubungan dengan saat pemasangan.
\end{abstract}

Kata kunci: R_inserter, IUD pascasalin, ekspulsi, infeksi, angka kelangsungan.

\section{ABSTRACT}

Background: IUD is one of the most effective and long acting contraception, but the rate of its use in Indonesia is still low. As conventional IUD inserter is too short to deliver it during immediate postpartum (postplacental) period, then the new inserter, R_inserter, is developped.

Objective:To find out whether the R_inserter can be used easily to deliver CuT-380A IUD during postpartum period in a standard procedure and to find out its safety.

Method: Phase II clinical trial, post-test observation.

Materials and Method: The IUD's used were the conventional CuT-380A with a modification on its inserter namely $9 \mathrm{~cm}$ longer, produced by PT Kimia Farma Indonesia. The study was carried out in three hospitals and three

\footnotetext{
1,2,3,4 Department of Obstetrics and Gynecology, Faculty of Medicine, Universitas Gadjah Mada/ Sardjito Hospital Yogyakarta

$5 \quad$ National Family Planning Board, Jakarta
} 
community health centers (Puskemas) which were the network of Sardjito teaching hospital, from January 2012 to April 2013. All eligible women needing IUD as their contraception were recruited. IUD insertion was carried out by trained obstetric and gynecology resident or midwives. Follow up was done after 1 week, then 1, 3, 6, 9 and 12 months after insertion.The ease of insertion, rate of the following events namely expulsion, infection, pain, bleeding, and continuation were main outcomes of interest.

Results and Discussion: During the study period, a total 142 participants were recruited. The mean duration of insertion was $3.89 \pm 2.08$ minutes (ranged 2 to 10 minutes). No subjective difficulties were perceived by the providers. The cumulative expulsion rate for 1, 3, 6, 9 and 12 months were $9.9 \%, 9.9 \%, 10.6 \%, 10.6 \%$ and $10 . \%$ consecutively. The rate of expulsion if the IUD was inserted during 10 minutes after placental delivery was $6.2 \%$ compared to $24.1 \%$ if it was inserted after 10 minutes (RR 3.90; 95\% Cl 1.37-11.2). Infection, pain, and bleeding were relatively small and could be appropriately managed. The continuation rate for 1, 3, 6, 9 and 12 months were $89.4 \%, 89.4 \%, 86.6 \%, 86.6 \%$ and $85.9 \%$ consecutively. No pregnancy was found during the study period.

Conclussion: The R_inserter could be easily used to deliver a CuT-380A IUD. The rate of expulsion was highest during the first month of insertion and was related to the time of insertion.

Keywords: $R_{-}$inserter, postpartum IUD, expulsion, infection, continuation rate.

\section{INTRODUCTION}

Indonesia with 237 million people (2011) is now occupying the fourth most populated country after China $(1,339,240,000)$, India $(1,184,766,000)$, and the United States (310 million). ${ }^{1}$ In 2007 the number of poor people reached $15.58 \%$ of the total population or 37.168 million. ${ }^{2} \operatorname{In} 2010$ it has dropped to 31.03 million, a decrease which was considered to be slow. ${ }^{3}$ Large population with less quality is a load of development so that the rate of population growth must be reduced.

The use of IUD (intra-uterine device) as a contraceptive in Indonesia is still relatively low at 7.2\% of all contraceptive use, smaller than the use of injectables (58.4\%), pills (24\%). ${ }^{2}$ Meanwhile IUDs meet several requirements such as cheap, effective, minimal side effects, practical, and easy to deliver provided that the service providers have been given adequate training. Based on the 1987 Demographic and Health Survey, the number of births in Indonesia reached 5.7 million per year, and $70 \%$ of them were conducted at health facilities. Suppose $20 \%$ of postpartum mothers were given IUD's for her contraceptives then the contribution of IUD for all use of contraceptives will increase significantly.
The use of postpartum IUD (immediate postpartum or postplacental IUD) has several advantages such as easy on insertion, the acceptors are clearly not being pregnant, it doesn't require a specific time to come, and patients are protected immediately after leaving the hospital. Nevertheless IUD should not be given without adequate counseling and informed consent of the patient. For that purpose, counseling of postpartum IUD insertion should have been given since a pregnant women is taking her antenatal care. Counseling done while the patient is in labor or delivery often leads to a regret for the decision is taken in an atmosphere that is not conducive. For clients who do not receive initial counseling it should be done after they are free from the stress and anxiety resulting from birth process.

IUD insertion techniques have been standardized using the "no touch and withdrawal technique". For CuT 380A, both arms shuld be bent and inserted into the tube inside the wrapper and should not absolutely be touched by hand although hands are using sterile gloves. Furthermore, IUD should be inserted into the uterus through the cervical canal without touching both the vaginal wall and the speculum. IUD is then placed in the fundus, hold the plunger and withdraw the tube slightly until the IUD is released. Then the 
tube is pushed upward toward the fundus until the IUD is placed high enough at the fundus. The tube is pulled out until it is released from the cervix and vagina, and the string is then cut and left about 1-2 $\mathrm{cm}$ from the os.

The IUD used for postpartum women so far is using a regular IUD which is inserted in 2 ways. The first way is by using two fingers (index and middle fingers) where the IUD is clamped between them and inserted into the uterine cavity through the dilated cervix, until it is attached at the fundus. The second one is using ring forceps in which the IUD is held at junction between the two horizontal arms and vertical bar and it is inserted throug the dilated cervical os and pushed deeply into the uterine fundus. ${ }^{4}$

Either way, it violates the principle of "no touch and withdrawal technique" that could potentially increase the risk of infection. Such procedures are taken because conventional package of CuT-380A IUDs available in the market is not specifically designed for postpartum IUD insertion.

The problem is that the length of inserter of the conventional package of CUT 380A IUD's currently availlable in the market, (produced byPT Kimia Farma Indnesia) is only $19.0 \mathrm{~cm}$ and it doesn't fit the depth of postpartum uterus. The principle of "no touch and withdrawal technique" becomes impossible because the entire inserter enters the vaginal cavity and no part of the inserter could be held.

Our previous study showed that the mean depht of the uterine cavity soon after (within 10 miutes) delivery of the placenta was $20 \mathrm{~cm}$ with the maximum of $28 \mathrm{~cm}$. Based on that finding the new inserter ( $R-$ inserter) was designed with the length of inserter become $28 \mathrm{~cm} .{ }^{5}$ No changes in the diameter of the inserter, so that this devise is also able to be used for interval or postabortal insertion. Using the new $\mathrm{R}$ _inseter the insertion of CUT 380-A IUD became easier and the pinciple of no touch and withdrawal technique become possible.

\section{OBJECTIVE OF THE STUDY.}

The aim of the present study was to find out whether the R_inserter could be easily used to deliver a postpartum IUD. It is also intended o find out the side effects and effectiveness of IUD use such as: expulsion, pain, bleeding, infection, removal, continuation and pregnancy rates.

\section{MATERIALS AND METHOD.}

The IUD used in this study was the CUT 380-A with a modified inserter on its length. It was prolonged by $9 \mathrm{~cm}$ to become $28 \mathrm{~cm}$. As this was the first study to try the easyness of the use of this inserter during post placental delivery period, we conducted a fase II clinical trial, where no control was needed. Post test observation was used.

The study was carried out in Sardjito and 2 other 2 hospitals, 3 Puskesmas that belonged to the networking of the teaching hospital of Faculty of Medicine Universitas Gadjah Mada Yogyakarta. It was started from January 1912 to April 2013.

Subjects (postpartum women) meeting the following criteria were included: all postpartum mothers needing IUD as their contraceptives, vaginal delivery, strong uterine contraction, no bleeding during the stage IV of labor and willing to carry out follow up visits. Pasients with signs and symptoms of intra-labor infection (chrioamnionitis), perineal laceration grade III to IV that tends to give rise postpartum infection were excluded.

IUD insertion was carried out by obstetric and gynecology residents of at least semester III or midwives after adequate training using standard no touch and withdrawal technique. Soon after delivery of the placenta, while uterine contraction was strong and no bleeding was encountered, the birth attendant changed his/her gloves. Patient was in lithotomy position, preparation of the vulva and vagina was carried out using $10 \%$ povidone iodine solution. Perforated sterile linen was applied. Anterior and posterior Sims speculums were inserted. The 
anterior lip of the cervix was grasped with a ring forceps to avoid tear. The depth of the uterine cavity was measured by uterine sound. The flange was then adjusted. As the external os of the cervix was still dilated, the IUD was inserted without putting both arms in to the tube and also without putting the plunger into the tube. While the right hand of the provider was inserting the IUD, the left hand was placed on the abdomen at the level of the fundus. Once the left hand felt that the IUD had been attaching at the fundus, the tube was withdrawn completely, and the IUD had been placed at the fundus. The tail of the IUD was not cut until one or two week-follow up.

Examination was done on follow up visits at 1 week, 1, 3, 6, 9 and 12 months. During each re-visit the followings were done: history taking, abdominal palpation, in-speculo examination especially to see the radix of IUD. Ultrasound examination was done in case of doubt that IUD was not in place.The IUD was said to be expelled if it was really recognized by the woman, a part of or the entier UD was seen through the external os. If the radix was not seen, then ultrasound examination was done to make sure whether it was still in situ or it was missing.

Infection was present if there was at least three of the following findings: elevated body temperature, pain on suprapubic or tenderness over abdominal palpation, foul smelling lochia or purulent vaginal discharge. Pain was a sensation complained or felt by the acceptor that she needed analgesics. Bleeding was defined as intermenstrual bleeding or menstrual blood flow perceived by the acceptor heavier or longger than usual.

\section{RESULTS AND DISCUSSION}

During three months period, 142 women meeting the eligibility criteria were recruited. The mean age and standard deviation was $27.9 \pm 5.8$ years with the minimum 14 years (one participant) and the maximum 40 years ( 3 participants). Most of them were between 20 to 35 years (Table 1). In this study, most women had one living child and none had more than 3 children (Table 2).

Table 1. Age of the women

\begin{tabular}{ccc}
\hline Age (years) & $\mathrm{N}$ & Percent \\
\hline$<20$ & 11 & 8 \\
$20-35$ & 114 & 80.3 \\
$>35$ & 17 & 11.7 \\
\hline
\end{tabular}

Table 2. Number of living children

\begin{tabular}{ccc}
\hline No of living children & $\mathrm{N}$ & Percent \\
\hline 1 & 76 & 53.5 \\
2 & 43 & 30.3 \\
$\geq 3$ & 23 & 16.2 \\
\hline
\end{tabular}

Ease of insertion was determined by subjective feeling of the providers (doctors or midwives) and the duration on insertion. None of the providersfound dificulties during insertion of these IUDs using the new $R$ _inserter. Duration of insertion is calculated from the application of the speculum until the inserter was pulled out completely. Mean duration of insertion was 3.89 minutes with the minimum of 2 minutes (38 cases or $26.8 \%$ ) and the maximum was 10 minutes (8 cases or $5.6 \%$ ).

Table 3. Duration of insertion in minutes

\begin{tabular}{ccc}
\hline Duration of insertion & $\mathrm{N}$ & Percent \\
\hline$\leq 5$ & 127 & 89.4 \\
\hline$>5$ & 15 & 10.6 \\
\hline
\end{tabular}

Table 3 showed that most of insertion was completed within 5 minutes or less. Fifteen cases took more than 5 minutes and only 8 cases $(5.6 \%)$ insertion took 10 minutes. This happened at the beginning of the study when the risidents or midwives were not so familliar with the technique. The author concluded

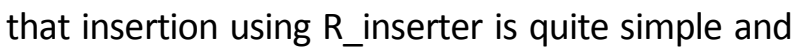
easy.

Time of insertion in this study was classifed in to two grups. The first, 113 cases $(79.6 \%)$ was within 
10 minutes after delivery of the placenta (post placental insertion) and the second, 29 cases (20.4\%) was within the first 48 hours after delivery (postpartum insertion).

During the first week follow up, the most prominent side effects found was expulsion (8.5\%) followed by pain $(3.5 \%)$ and infection $(0.7 \%)$. No other side effects were encountered. At one monthfollow up visit, expulsion and pain were still dominant. One case had IUD removed because of pain and infection unresponsive to analgesic and antibiotic treatment.

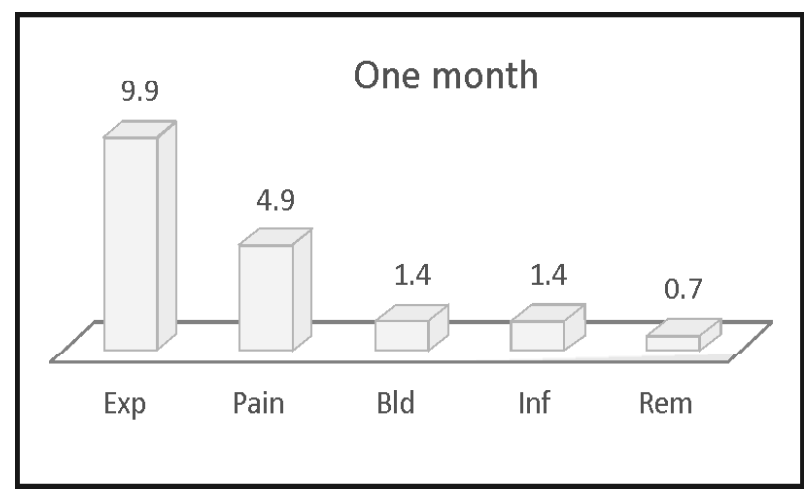

Figure 1. Cummulative events rate at one month follow up (\%). Exp, expulsion; Bld, bleeding; Inf, infection; Rem, IUD removal.

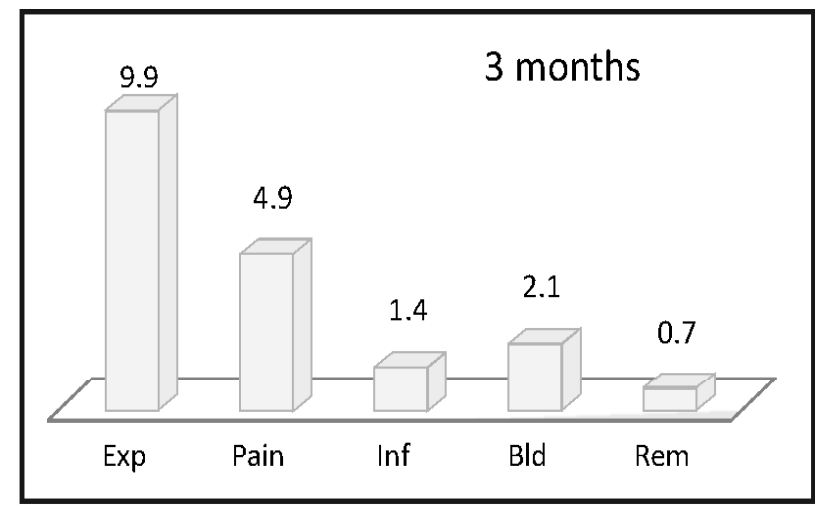

Figure 2. Cummulative events rate at three months follow up (\%). Exp, expulsion; Bld, bleeding; Inf, infection; Rem, IUD removal

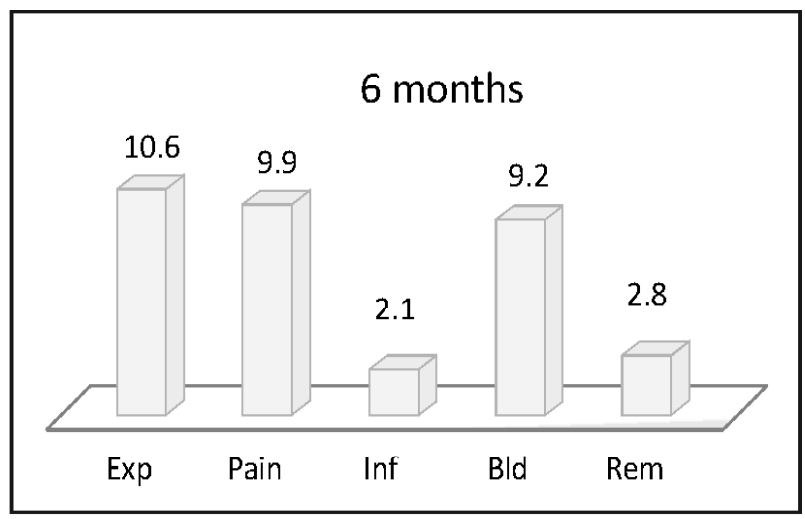

Figure 3. Cummulative events rate at six months follow up (\%). Exp, expulsion; Bld, bleeding; Inf, infection; Rem, IUD removal

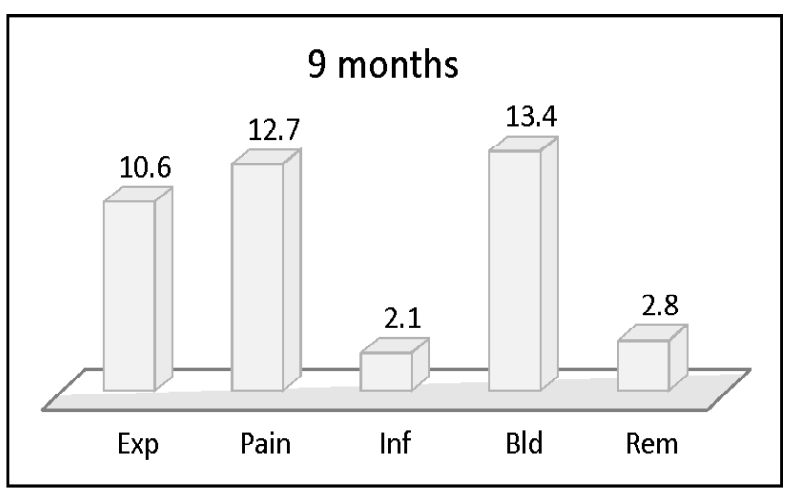

Figure 4. Cummulative events rates at nine months follow up (\%). Exp, expulsion; Bld, bleeding; Inf, infection; Rem, IUD removal.

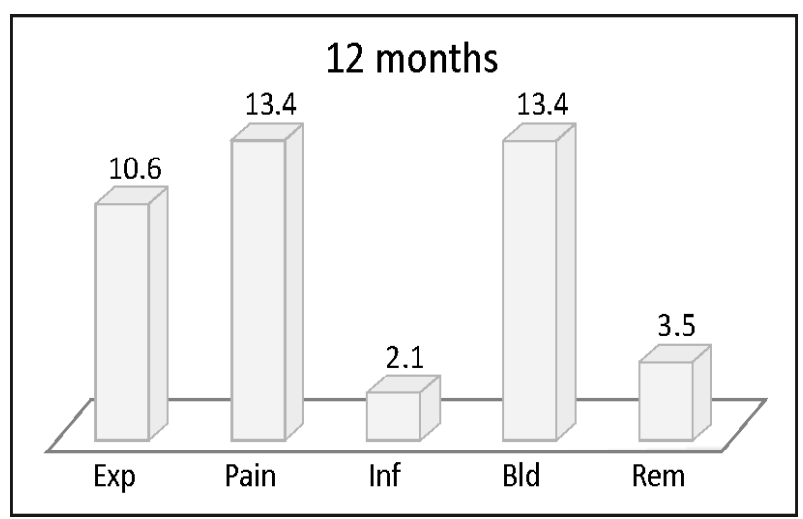

Figure 5. Cummulative events rates at twelve months follow up (\%). Exp, expulsion; Bld, bleeding; Inf, infection; Rem, IUD removal. 
The first multicentre study of postplacental IUD was done on the late 1970s who involved 841 women, using three types of IUD: Postpartum T, Lippes Loop D (LLD), and Coper 7-200. During 12 months observation, no uterine perforation was reported but the pregnancy rates of Postpartum $T$, LLD, and Cu7-200 were 5,6, 12,1 and 7,3 per 100 women respectively, while the expusion rates were 41, 44 and 35 respectively. The study was terminated prematurely by the WHO because the pregnancy and expusion rates exceeded the stopping rules set in the study protocol, namely pregnancy rate below 3 per 100 women-years and expulsion rate below $20 .{ }^{6}$

The main event in our present study was expulsion happened during the first month after insertion reaching 9.9\% and it continued untill the sixth months of use i.e. $10.6 \%$. No more expulsion was found until the end of the 12th month observation (Fig.5). This didn't much differ from the study of Xu et al. ${ }^{6}$ conducted in China showing that the one year cummulative expusion rate was $10.8 \%$ (95\% $\mathrm{Cl} 8.02$-13.76) for manual insertion and $11.8 \%$ $(95 \% \mathrm{Cl} 8.31-14.24)$ for ring forceps insertion.

A review conducted by the WHO demonstrated that expusion was a major concern because the rate was relatively high, namely between $6 \%$ to $44.1 \%$ during the period of 6 to 36 months of use respectively. ${ }^{7}$ Other studies showed that immediate postpartum IUD insertion had expulsion rate higher than insertion during interval period. Expulsion by six months was more likely for the immediate group than the delayed insertion group (OR 6.77; $95 \% \mathrm{Cl}$ 1.43 to 32.14$){ }^{8}$

The 12 months cumulative bleeding rate in this study was $13.4 \%$ in the form of spott bledding or menorrhagia and were perceived not to be too annoying. This could be managed by the administration of tranexamic acid. None asked to be removed unless one acceptor because infection with endometritis. A systematic review showed a range between $4.6 \%$ to $12.7 \%{ }^{9}$

Talking about the association between the rate of expulsion and time of insertion it was interesting that number of women who underwent expusion happened mainly when IUD was inserted beyond 10 minutes after delivery of the placenta. The following table showed that expulsion rate was much more higher when IUD was inserted after 10 minutes of the delivery of the placenta (Table 4).

Table 4. Risk of expulsion based on time of insertion

\begin{tabular}{|c|c|c|c|c|}
\hline \multirow{2}{*}{$\begin{array}{c}\text { Time of insertion } \\
\text { after delivery of } \\
\text { placenta }\end{array}$} & \multicolumn{2}{|c|}{ Expulsion } & \multirow{2}{*}{$\begin{array}{l}\text { Percent of } \\
\text { expulsion }\end{array}$} & \multirow[b]{2}{*}{$\operatorname{RR}(95 \% \mathrm{Cl})$} \\
\hline & Yes & No & & \\
\hline$>10$ minutes & 7 & 22 & 24.1 & \multirow{2}{*}{$3.90(1.37-11.12)$} \\
\hline$\leq 10$ minutes & 7 & 106 & 6.2 & \\
\hline
\end{tabular}

No pregnancy was observed during 12 months follow up. Number of women who didn't use IUD any more had been seen since the first week of use because of expulsion and it continued until the six month of observation because of either expulsion or they had the IUD remomed for any medical reason.Two cases had the IUD removed because of infection unresponsive to antibiotic treatment and four cases due to bleeding and spotting. Nineteen women discontinued using the IUD after 12 months of use, consisting of 15 expulsions and 4 removals because of medical reason giving the continuation rate $85.9 \%$ for one year (Fig.6). A systematic review showed that continuation rate of postpartum IUD use ranged from $57 \%, 84 \%$ to $93.3 \%{ }^{9}$ 


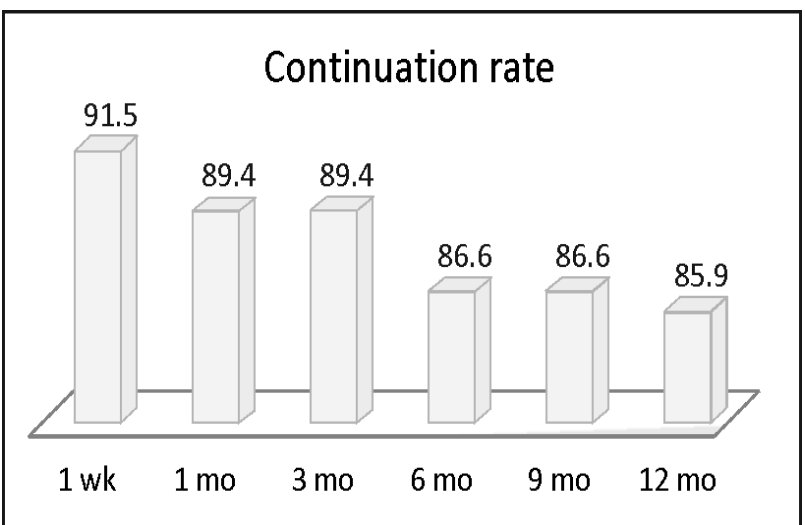

Figure 6. Continuation rate during twelve months follow up (\%).

\section{CONCLUSION}

The $R$ _inserter could be used easily and safe. The main event was expulsion that mainly happened during the first month after insertion. Other side effects were infection and pain that could be managed by antibiotic and analgesic treatment. Bleeding was usually minimal in the form of prolonged or inter-menstrual bleeding which could be managed by tranexamic acid. No pregnancy was observed during one-year follow up.

\section{REFERENCES}

1. Anonym. Population Data Sheet 2012. Population Reference Bureau. 2012.

2. Kusumobroto BS, Purwanto UT, Hasnawati dan Brahim R. Profil Kesehatan Indonesia 2007. Depkes RI 2008.
3. Anonym. Demographic Health Survey 2012. Biro Pusat Statistik - Kementrian Kesehatan Indonesia. 2012

4. Xu JX, Rivera R, Dunson TR, Zhuang LQ, Yang L, Ma T and Chi I-c. A Comparative study of Two Techniques Used in Immediate Postplacental Insertion (IPPI) of the Copper T-380A IUD in Shanghai, People's Republic of China. Contraception. 1996;54:33-38

5. Siswosudarmo, HR. Pengukuran kedalaman Uterus Pascasalin. Bagian Obstetrika dan Ginekologi Fakultas Kedokteran UGM - RS Sardjito Jogjakarta, 2011

6. Xu JX, Reusche C and Burdan A. Immediate postplacental insertion on the intrauterine device: a review of Chinese and the world experience. Advance in Contraception. 1994;10:71-82

7. Immediate postpartum insertion for intrauterine devices. Available at: http://apps.who.int/rhl/ fertility/contraception/cd003036_muthalrathorea_ com/en/index.html

8. Grimes DA, Lopez LM, Schulz KF, Van Vliet HAAM, Stanwood NL. Immediate post-partum insertion of intrauterine devices. Cochrane Database of Systematic Reviews 2010, Issue 5. Art. No.: CD003036. DOI: 10.1002/14651858.CD003036. pub2 intrauterine device: a review of Chinese and the world's experiences Immediate postplacental insertion of the intrauterine device: a review of Chinese and the world's experiences.

9. Kapp N and Curtis KM. Intrauterine device insertion during the postpartum period: a systematic review. Contraception. 2009;80:327-336 